\title{
Financing of Women-Owned Ventures: The Impact of Gender and Other Owner- and Firm-Related Variables
}

\author{
CHRISTINA CONSTANTINIDIS, ANNIE CORNET \& \\ SIMONA ASANDEI \\ HEC Business School, University of Liège, Belgium
}

(Accepted 5 January 2006)

\begin{abstract}
While women-owned ventures represent an increasing proportion of new businesses in most western countries, most of them have particular financing patterns and encounter barriers in their access to financing. Recent research on the question argues that barriers to financing are mainly dependent on factors other than gender, such as owner-and firm-related characteristics. This quantitative and qualitative study, through descriptive statistics and interview analysis, examines the relationship between financing patterns and barriers and gender from the woman entrepreneur's viewpoint. It explores the behaviours and representations of women entrepreneurs towards financing, and considers to what extent the women see their own approaches as being different from those of men. Our study suggests that a gender effect still exists, and tries to identify its location and the corresponding implications for further research and action.
\end{abstract}

KEY WORDS: Women entrepreneurs, business financing, gender

\section{Introduction}

It is widely acknowledged that women-owned businesses represent an ever increasing proportion of new ventures in most western countries, and that they make a substantial contribution to entrepreneurial dynamics. However, several studies (see Gatewood et al., 2003) have shown that women entrepreneurs seem to have particular financing patterns. In addition, despite recent progress, they encounter more barriers than male-owned ventures in accessing financing, which is critical at the different stages of business creation and development.

In order to analyse this subject, we need to make a distinction between demandside patterns (behaviours of women entrepreneurs) and supply-side patterns (behaviours of bankers and public funders). On the demand side, previous studies have reported that the initial capital invested in women-owned businesses is smaller

Correspondence Address: Christina Constantinidis, University of Liège, Boulevard du Rectorat, $\mathrm{n}^{\circ} 7, \mathrm{~B} 31$ (bte 48), Sart-Tilman, 4000 Liège, Belgium. Tel: +32 (0)4 36636 84; Fax: +32 (0)4 36627 67;

Email: christina.constantinidis@ulg.ac.be 
than in men's and that women mainly have recourse to their personal savings, credit cards or loans from family and friends in order to finance their business, rather than using bank loans or commercial credit (Carter and Rosa, 1998; Cliff, 1998; Cooper Maysami and Goby, 1999; Coleman, 2000; Orhan, 2001; Robb and Wolken, 2002; St Cyr, 2002). Coleman (2004) found that women are significantly less likely than men to take out a loan, including a line of credit, which is considered to be the most flexible type of loan from the standpoint of a small business. As already stated, women entrepreneurs seem more likely to borrow using credit cards than men, a type of credit which is seen as more expensive and hence an imperfect substitute for loans. Figures from the Center for Women's Business Research (2005) show that, in the US, only one-third of female business owners used commercial credit in 2003 and that most equity financing acquired by women entrepreneurs was acquired through personal sources: $73 \%$ received investment from family and friends and $73 \%$ from angel investors. Chaganti et al. (1995) also stated that women entrepreneurs tended to use internal sources of equity, rather than external sources. Robb and Wolken (2002) also found that women owners were significantly less likely to have applied for a loan within the previous three years than men, revealing lower application rates.

On the supply side, a study by the Center for Women's Business Research (2000) showed that women's entry into the venture capital sector was quite recent. Twentytwo per cent of US Small Business Administration programmes involved women and only $4 \%$ of venture companies were women-led. With respect to equity financing, Greene et al. (2001) found that, in 1998, less than 5\% of all US venture capital investments was invested in firms owned by women.

Some authors suggest that women meet specific barriers to obtaining capital for starting a business (OECD, 2000). They also encounter barriers to obtaining external financing, in particular debt financing through bank loans, and barriers to equity financing through venture capital and business angels (Ratté, 1999; Légaré, 2000; OECD, 2000; Danmanville and Hurel, 2001; St-Cyr, 2002). Some studies have explored the assumption that the rejection rate of bank loan applications may be higher for women than for men entrepreneurs. A study from the Canadian Bankers' Association (CBA), in 1997, showed that the rejection rate of bank loan applications amounted to $23 \%$ for women-owned businesses, compared with only $14 \%$ for menowned ventures (St-Cyr et al., 2003). Moreover, Orhan (2001) showed that, in France, women-owned businesses were asked for higher collateral requirements and charged a higher interest rate than similar men-owned ventures, when borrowing from banks or other financial institutions. Other researchers defend the idea that the problems are due to the owner and the firm's characteristics and not to the sex of the owner. ${ }^{1}$ For example, Robb and Wolken (2002) found no significant differences between male and female entrepreneurs in terms of approval rates when they applied for new credit, nor in terms of loan terms or loan amounts.

Our research analyses the entrepreneur's viewpoint. It also explores behaviours and representations of women entrepreneurs towards financing and the extent to which the women see their approaches as being different from those of men. We will study women's representations of their own competence, of their firm's evolution and of the way that financiers perceive their reality and behave towards them. The first section consists of a literature review focusing on the different factors explaining the specific financing patterns and barriers experienced by female-owned firms. 
A description of the research methodology follows. Results are then presented. We will not present these in detail, ${ }^{2}$ focusing rather on the additional data and information brought forward by our study, with regard to our topic. We will show that women are not a homogeneous group, but represent multiple realities. In all cases, we find a gender effect playing a role at different levels: (1) regarding the choices of women in terms of business characteristics (business sector, size, growth); (2) regarding the self-perceptions of women, and representations toward and relationships with investors. Finally, we present a discussion around the different categories of women entrepreneurs, and the outcomes in terms of financing patterns and barriers encountered by their businesses. We also discuss the implications for further research and forms of action, such as desegregation initiatives, designed to encourage women to take an interest in traditionally male sectors, but also to valorize their own sectors and activities.

\section{Background and Research Questions}

Several specific financing patterns and barriers experienced by women-owned businesses have been identified in the previous section. In this review, we present the different factors used to explain the differences observed between men and women regarding financing patterns. We make a distinction between a firm's characteristics and strategic choices (characteristics of the firms) and individual factors (characteristics of the women and their way of doing business).

If the different studies agree that there are differences between men and women in financing patterns, the authors do not agree about the gender effect. Thus, several authors state that entrepreneurship, and more specifically business financing of female-owned businesses, should not be studied as an effect of gender issues, particularly in terms of discrimination against women, but from the perspective of the firm and owner's characteristics. These authors argue that barriers to financing faced by women-owned businesses are dependent on factors such as the attributes of female-owned firms (i.e. the firm's characteristics and strategic choices), the characteristics of women owners and the way women approach and run their ventures (i.e. individual factors). The hypothesis in these theses is also that, if women were to invest in other sectors and have more similar characteristics to male entrepreneurs, differences would not exist between the financing patterns of men and women business owners.

\section{A Firm's Characteristics and Strategic Choices}

The existing differences regarding the financing of men- and women-owned businesses can be explained by the characteristics of their firms. Four main factors are identified in the literature: sector, size and age of the firm and its property structure. Gatewood et al. (2003) used the concept of strategic choice, which includes industry type (sector), product-market segment, location, innovative or imitative strategy, competitive positioning and growth rate.

Women generally start new or micro-businesses in traditional, low-growth industries (mainly service and retail), with a low-growth profile and higher risk. Moreover, women are, more often than men, sole owners. These characteristics 
could explain the smaller initial capital invested in start-up by women entrepreneurs, in comparison with their male counterparts and make them less appealing to potential financiers (Orhan, 2001; Heidrick and Nicol, 2002). Orhan (2001) argued that women, running small business projects without growth opportunities, require only small amounts of money and thus may be reluctant to borrow small amounts, as the interest rate would be higher than for bigger projects. St-Cyr et al. (2003) talk of a vicious circle, whereby the small size and low-growth profile of women-owned businesses impedes their access to bank financing, and this lack of bank financing limits, in turn, women entrepreneurs' growth opportunities. Robb and Wolken (2002) found that credit used by female- and male-owned businesses differed primarily according to their business credit history and to the risk associated with their ventures. Women seem to run younger and riskier firms, with a poor credit history and thus are less likely to apply for loans, for fear of denial. Many authors argue that these business characteristics influence the needs and preferences of women entrepreneurs for financing, as well as their access to funding (Ratté, 1999; Légaré, 2000; OECD, 2000; Danmanville and Hurel, 2001; Robb and Wolken, 2002; St-Cyr, 2002). Various authors stated that, after accounting for structural differences between men- and women-owned businesses, no difference remained in the rate of loan rejections, nor in other measures of credit (Riding and Swift, 1990; McKechnie et al., 1998; Heidrick and Nicol, 2002). So the decision to invest or not in a business seems to depend primarily on the overall risk and return associated with the firm, the stage of the venture, the type of financing and the type of industry.

For these authors, women's lack of access to debt financing would seem to be related more to the characteristics of women-owned businesses, than to the owner's sex. Moreover, the Angus Reid report (2000) found that, in many cases, these factors were coupled with an undeveloped personal credit history and absence of collateral, which were reported by women as important barriers to finding debt financing for their businesses (Angus Reid Group, 2000, pp. iii-iv). Robb and Wolken (2002) showed that a firm's credit history, as well as the owner's credit history in the case of small businesses, is an important determinant of whether a firm can obtain credit, as measured by Dun and Bradstreet's credit score. Carter and Rosa (1998) also underlined the existing link between a weak business track record and a loan refusal. Heidrick and Nicol (2002) revealed that the more mature businesses are perceived to be at lower risk for financing and thus financing is made on the strength of the existing venture rather than the owner's characteristics. We also find the idea that women create innovating companies, for which banks cannot use benchmarking (Ratté, 1999; Légaré, 2000; OECD, 2000; Danmanville and Hurel, 2001; St-Cyr, 2002). These factors and explanations are summarized in Figure 1.

In our research, we plan to see if we can find similar results across Belgium. However, we also intend to use gender analysis, especially with regard to the following: sector choice, the decision to start up and to keep the firm small and the level of influence of the firm and owner's credit history on the women's perception of investor behaviours (demand side).

$R Q 1$ : How can we explain the choices made by women about business sector, size, type of association ${ }^{3}$ and their impact on their behaviours regarding financing? Can gender theories contribute to better explain this? 


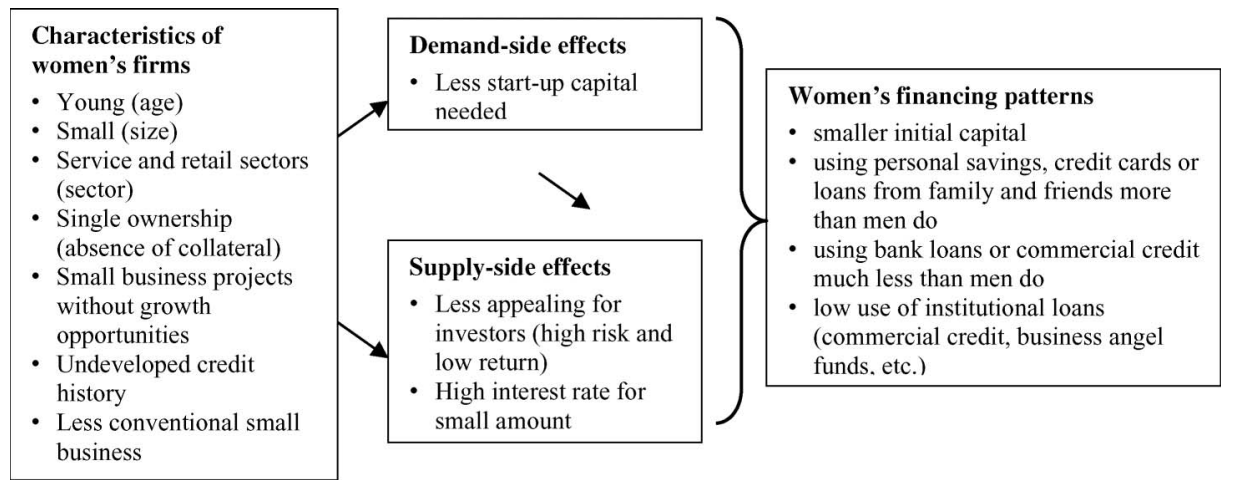

Figure 1. Impact of firm's characteristics and strategic choices on the financing patterns of women-owned firms

\section{Individual Factors}

Research shows that, beyond business features, the characteristics of women entrepreneurs themselves, as well as their perceptions and preferences, can also have a strong impact on their financing patterns. Gatewood et al. (2003) make a distinction between human capital (experience, education, functional experience), social capital (social and business relationships), financial capital, and personal cognitions and goals (push and pull motivations, cognitive styles).

Most women entrepreneurs have a low level of education and this could already be a specific barrier to financing. For Coleman (2004), when educational level is included in the analysis as an independent variable, many of the gender differences in the use of loans disappear. When educational level is taken into account, women entrepreneurs are no less likely to apply for loans.

Several authors suggest that differences in financing patterns and in access to funding between men and women entrepreneurs may also come from women's lower financial and managerial or entrepreneurial competence (Ratté, 1999; Légaré, 2000; OECD, 2000; Danmanville and Hurel, 2001; Greene et al., 2001; Orhan, 2001; St-Cyr, 2002). It seems that women may have fewer opportunities to accumulate human capital, due to their former status, including lower wage and less managerial experience (Boden and Nucci, 2000). Due to the lack of financial competence, women have difficulty in developing a medium-term business plan and feel insecure in financial negotiations. Shragg et al. (1992) showed that these negative selfperceptions can be a barrier to financing for women entrepreneurs. On the supply side, the perception of women as having less business management experience or less financial competence might lead bankers to reject the loan applications of women entrepreneurs (Fabowale et al., 1995; Haines et al., 1999).

Research also shows that many firms owned by women might not be able to access financing sources because women have no personal assets or have an insufficient personal financial contribution necessary for starting a business or for constituting a guarantee (Ratté, 1999; Légaré, 2000; OECD, 2000; Danmanville and Hurel, 2001; Heidrick and Nicol, 2002; St-Cyr, 2002). This can be a significant barrier to accessing 
financing for early stage ventures, where the investment is being made based on the owner's personal characteristics. Moreover, female owners are often younger than male entrepreneurs and have a comparatively poor credit history (Robb and Wolken, 2002).

Some authors also suggest that women entrepreneurs are not sufficiently informed about the various ways to finance their companies (micro-financing, private investment, public programmes in favour of women) (Ratté, 1999; Légaré, 2000; OECD, 2000; Danmanville and Hurel, 2001; Heidrick and Nicol, 2002; St-Cyr, 2002). This could be linked with the low representation of women entrepreneurs in established networks, where they could find information on business financing possibilities (Carter et al., 2003). This seems to have a significant impact, especially on access to equity financing, which is indeed very difficult to obtain if the business owner lacks network contacts (Greene at al., 2001; Heidrick and Nicol, 2002).

Some authors suggest that women are not assertive, competitive or self-confident enough and, as lending institutions pay great attention to the abilities and the 'entrepreneurial profile' of the business owner, women may not fit the stereotypical 'entrepreneur' profile.

Buttner and Rosen (1992) and Fabowale et al. (1995) both noted that, while there was no evidence of differences in access to credit between male and female entrepreneurs, women were more likely to report feelings of being treated disrespectfully by financial institutions. Regarding this last statement, we can assume that these quite negative representations and feelings of women entrepreneurs towards bank financing may also impede them from even applying for a bank loan.

Research also highlights notable differences in the way that women approach and run their ventures and in the way that they envisage their own needs, many of these being directly or indirectly related to financing patterns (Brush, 1992; Heidrick and Johnson, 2002). In different studies, women entrepreneurs are shown to be less oriented towards growth (Kangasharzu, 2000; St Cyr, 2002), and those who do want to achieve growth, wish to do so without recourse to external partnerships (Cliff, 1998; Coleman, 2000; Orhan, 2001), especially as regards to venture capital funding (Greene et al., 2001). Linked to this profile is also the idea that women are risk-averse and have a willingness to reserve time for family needs. Brush (1997) showed that childcare could inhibit growth of women-led firms.

Women entrepreneurs have to cope with the demands of their business and their family responsibilities, and this 'double burden' can have an impact both on their ability and on their willingness to go into debt. Indeed, the double familial and professional responsibility increases women's risk-aversion, leading them to request smaller amounts of credit and can also lead to a mistrust of creditors (Carter and Rosa, 1998; Ratté, 1999; Légaré, 2000; OECD, 2000; Danmanville and Hurel, 2001; St-Cyr, 2002).

These individual factors and explanations are summarized in Figure 2.

$R Q 2$ : How can we explain the characteristics of women entrepreneurs and the impact of these characteristics on the women's representations and behaviours regarding financing? Are women entrepreneurs a homogeneous group? What about the situation of women who have similar characteristics to those of the male entrepreneur? Can we identify gender effect? 


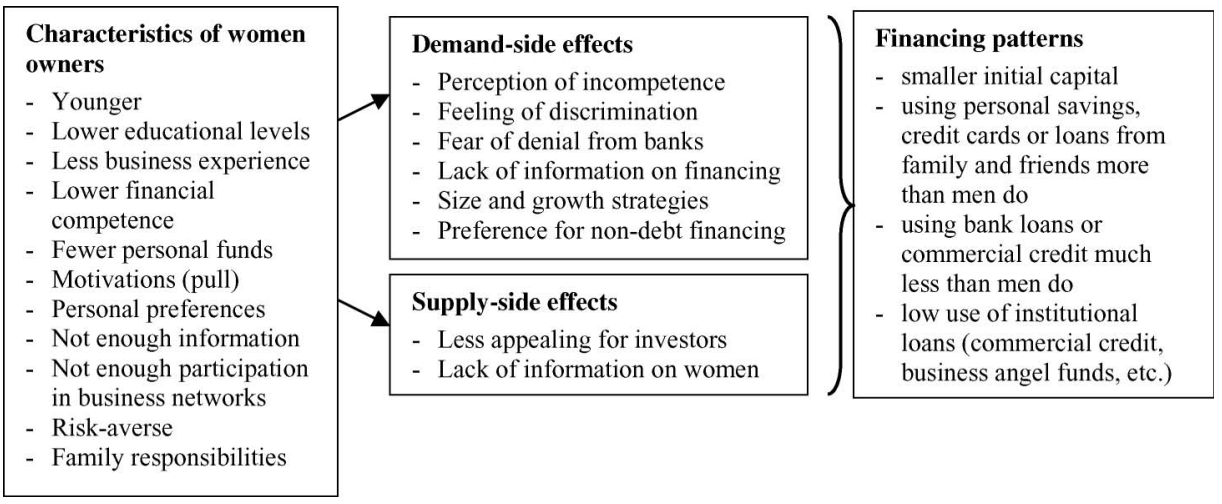

Figure 2. Impact of individual factors on the financing of women-owned firms

We compare our results with other research (regarding owner and firm's characteristics). However, we also want to propose a gender analysis, not defined as identifying differences between men and women, but as an analysis of social relations and social structures (Connell, 2002). This analysis is organized around two principles (Kergoat, 2000, p. 36): separation (specific competencies, tasks, jobs and sectors for men and women) and hierarchy (more attention and valorization for men's activities, which are seen as more complex).

\section{Methodology}

Our research methodology was a dual one, including both a quantitative and a qualitative study. A stratified sample (distribution of female-owned businesses by region and sector) was constructed for the quantitative survey. Approximately 1100 questionnaires were distributed, mainly by post, to female entrepreneurs randomly selected from the file provided by the National Social Security Institute for the SelfEmployed. The sample was composed of female administrators of commercial companies and self-employed women (non-incorporated companies), including women professionals (doctors, lawyers, etc.). A number of recalls were made in order to guarantee a higher participation in the survey. The response rate was $22 \%$ in Wallonia (French- and German-speaking regions, 131 questionnaires) and $30 \%$ in Flanders (Dutch-speaking region, 157 questionnaires). The final distribution of businesses in our sample is represented in Figure 3.

In Belgium, in 2002, women represented $30 \%$ of the self-employed and $30 \%$ of owners of commercial firms (16\% as principal owner and $13 \%$ as associate). If we compare the distribution of our sample with the distribution of women entrepreneurs in Belgium, ${ }^{4}$ we can note an underrepresentation of this industry sector in our sample.

The questionnaire was jointly developed by researchers from the University of Liège (Belgium) and from the University of Limburg (Belgium). Its content is based on a detailed literature review, on questionnaires written by Louise St-Cyr from 


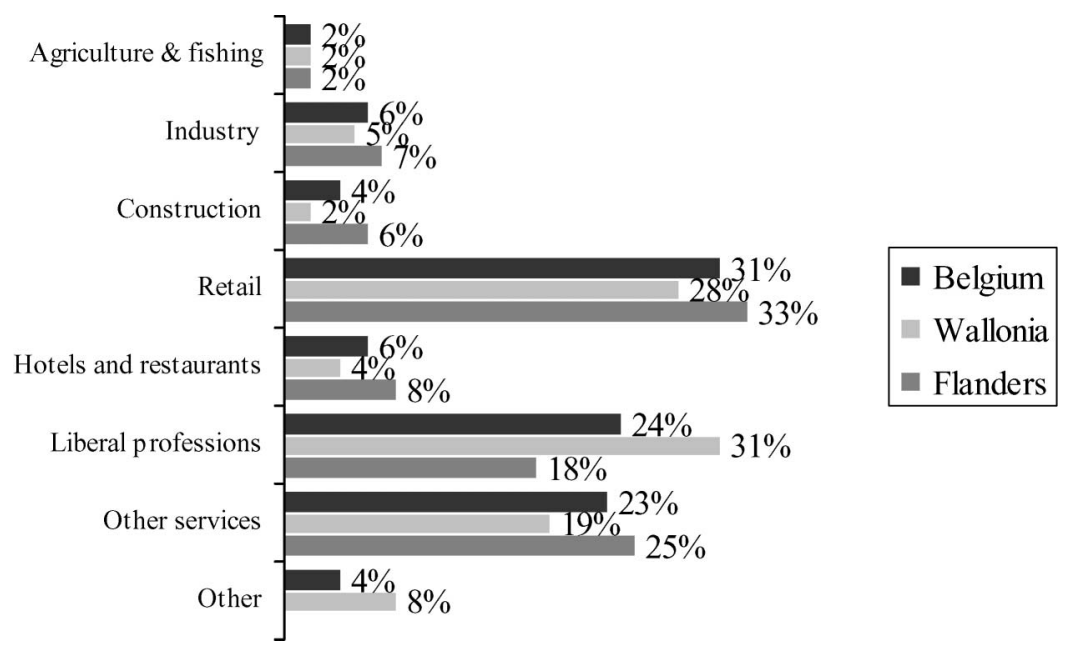

Figure 3. Sample distribution of female-owned businesses by region and sector

HEC Montréal, ${ }^{5}$ on project partners' experience and on preliminary surveys conducted by one of our partners. ${ }^{6}$ The questionnaire was divided into three sections: a profile of women-owned ventures; a profile of female entrepreneurs, financing patterns and needs in managing processes; training, networking and entrepreneurship support.

We used the 'Statistical Package for the Social Sciences (SPSS) 11.0' in order to analyse the quantitative data: descriptive statistics, contingency tables and corresponding association measures (dependence tests - chi-square and adjusted residuals), along with multivariate analysis. The sample size sometimes necessitated careful analysis (namely when analysing subgroups) in generalizing conclusions to the entire population.

The qualitative survey comprised 25 in-depth individual interviews and several focus groups with Belgian female entrepreneurs. In the results section, the interviews are identified by the symbols M1, M2, etc., up to M25, representing the number of the interviewee. The selection of respondents for the in-depth interviews was carried out by taking into account the business sector, the owner's age and the family situation. All interviews were recorded and fully written up. Focus groups were conducted with female entrepreneurs, various entrepreneurship training and support intermediaries and financial world representatives. We used content analysis to examine the qualitative information obtained, including structural qualitative analysis, based on the identification of associations between ideas. Qualitative interview analysis can help to understand quantitative results, and therefore offers added value.

As we do not have a comparative sample of male entrepreneurs, our data do not enable us to analyse differences between women and men. Our objectives were not to make a comparison but to identify and to understand women's behaviours and representations in a research action process: our results had to be useful for a service providing assistance to women in entrepreneurship. 


\section{Empirical Results}

In the following section, we will present some results of our study, as regards the relationship between women entrepreneurs' financing patterns and organizational and individual factors. Our research analyses the demand side (the entrepreneur's viewpoint) and explores the behaviours and representations of women entrepreneurs towards financing. It also considers to what extent the women see their own behaviours and representations as being different from men's.

\section{Women's Financing Patterns}

This section presents descriptive statistics for (1) the amount of initial capital invested by women for their business start-up; (2) the use of bank loans for the financing of women's business start-up; (3) the number of applications for bank loans during the previous five years of existence of women-owned businesses; and (4) requests for bank financing granted during the previous five years. We will see that our results are congruent with other research results, except for the use of bank loans, which are more frequent in our sample than in other studies.

(1) Amount of initial capital invested for business start-up. Of 288 self-employed women, $58(20 \%)$ did not need to finance their business start-up (for example, because of an inheritance). Our statistical analysis therefore relates to 218 female entrepreneurs (12 did not answer the question). As expected, women entrepreneurs seem to invest low amounts in start-up. Of 218 female entrepreneurs, $45.6 \%$ invested less than $€ 25000,{ }^{7}$ while only $20.4 \%$ of women invested more than $€ 75000$ (Figure 4 ).

(2) Use of bank loans for business start-up. For the launching of their businesses, the financing sources that female entrepreneurs used the most were bank loans $(71 \%$ of women) and personal savings (65\% of women). Some women also mentioned loans from family and friends $(24 \%)$. It seems that women entrepreneurs use bank loans to a greater extent for the start-up stage. These results are rather different from those of other studies undertaken on the financing of female-owned ventures, which underlined the small use of bank loans by women entrepreneurs, especially for the start-up stage. In terms of financing sources used, the larger the amount needed,

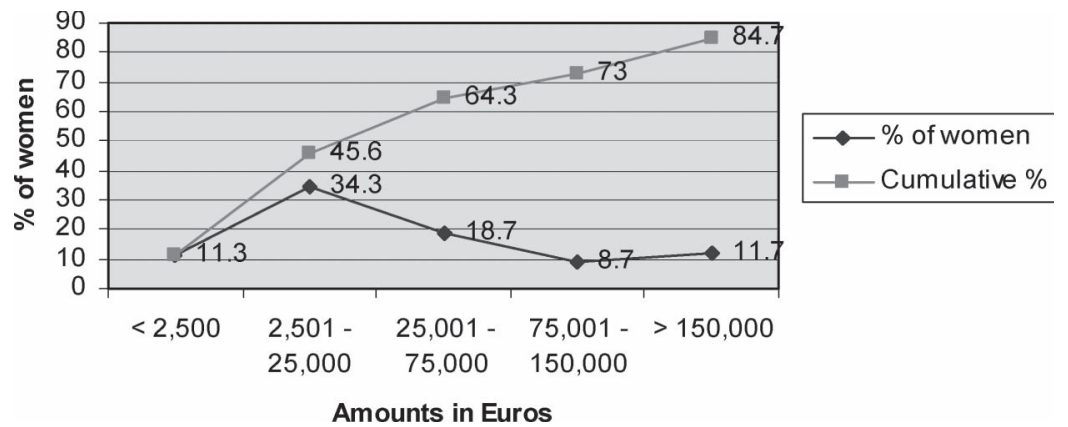

Figure 4. Amounts invested in business start-up 
the more bank loans were used. On the other hand, for small amounts, female entrepreneurs used their personal savings, loans from family and friends and/or their firm's capital. The use of bank loans was also linked with the number of employees.

(3) Bank loan applications during the business development process. In order to assess the need for bank credit by women entrepreneurs for expansion purposes, we asked them whether they had applied for bank financing during the previous five years and about the number of requests they had made during that period. We found that only $48.6 \%$ of female entrepreneurs (140 out of 288 ) had made at least one request for a bank loan. More precisely, 62 out of these 140 self-employed women had made only one request $(21.5 \%), 67(23.3 \%)$ had made between two and five requests, while only 11 women entrepreneurs $(3.8 \%)$ had made more than five requests for bank financing during that period. It is important to note that almost half the women entrepreneurs had not applied for a loan at all during the previous five years (Table 1, Figure 5).

(4) Requests for bank financing granted during the previous five years. When we asked questions about barriers they had met in access to start-up financing, $43 \%$ of women owners from our sample spoke of this problem. However, $86 \%$ of requests made by the female entrepreneurs to banks during the previous five years had been accepted. In other words, 129 out of the 150 self-employed women, who had applied for at least one bank loan, saw all their requests accepted (Table 2, Figure 6). We need more qualitative data to understand this paradox.

\section{A Firm's Characteristics and Strategic Choices}

Our quantitative data show that business sector and size influence the amount of initial capital invested, the financing sources used for business start-up, and the relative use of bank loans for business start-up and expansion.

Business sector and size. It was found that $21.1 \%$ of women entrepreneurs, who did not have salaried staff (the majority of those in the service and retail sectors),

Table 1-Figure 5. Number of requests for bank financing during the previous five years

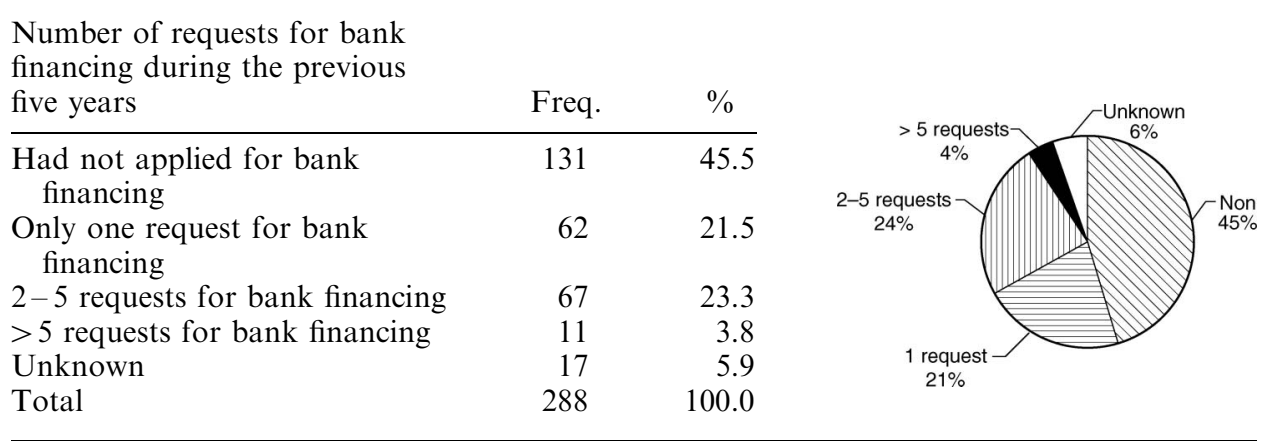


Table 2-Figure 6. Proportion of requests for bank financing granted during the previous five years

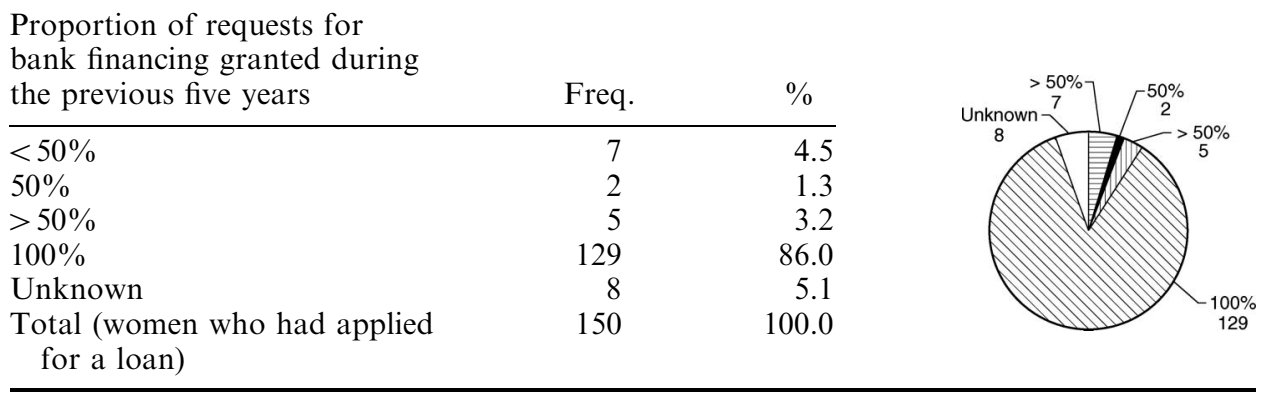

had invested less than $€ 2500$, compared to $13.6 \%$ of women of the total sample. They tended to use fewer bank loans for their start-up financing compared to others and to use more personal savings. Only $41 \%$ of the women, who had applied for a bank loan during the previous five years, had no employees, in comparison with $50 \%$ of women in the whole sample. Women in the service and retail sectors tended to favour personal savings or family loans. They had been less inclined than others to apply for a bank loan during the previous five years of their firm's existence $(54.7 \%$ of female-owned firms in the service and retail industries). The global proportion of women-owned firms was $59.4 \%$.

This contrasted with women professionals who seemed to need more external funds. Women professionals (and to a lesser extent, women in the industrial sector) were comparatively more likely to apply for bank loans $(27.3 \%$ of women who applied for external funds were professionals and constituted $24 \%$ of our sample). Women professionals were likely to be sole owners or to create small ventures with very few employees.

Self-employed women in the industrial sector tended to invest higher amounts than others: $21.4 \%$ of women in this sector invested more than $€ 150000$ in start-up, compared to $11.7 \%$ of women of the total sample. Firms in the industrial sector are likely to be quite large and to employ many people. As regards business size (in terms of employment), the greater the number of people employed, the higher the amounts invested in start-up. It was found that $33.3 \%$ of women, who had more than 50 employees, invested more than $€ 150000$ in start-up, compared to $14.1 \%$ of women in the total sample. Female entrepreneurs who took over an existing company (whether a family enterprise or not) tended to pump more money into the business when taking it over than did those who were creating a new venture. Women who were in this situation explained this by factors relating to the stage of business maturity (cash flow and credit history of the firm). Women owners in the industrial sector tended to use more bank loans for their start-up financing, and not much of their personal savings or family loans.

Our results confirm that a firm's characteristics and strategic choices influence the financing patterns of women entrepreneurs. We can observe differences between the sectors and also an influence of company size. The qualitative data taught us that sector choice could also be made as a result of financing constraints. Some women 
decided to create a firm in the retail or service sector because it is possible to begin an activity in these sectors without a large amount of funds. We will link this information later with the characteristics of women owners.

We can also see that the behaviours of women entrepreneurs in the industry sector seem to be similar to men's (larger amounts of capital, use of bank loans, etc.). However, our results also show that, even if women are in the industry sector, when they have achieved a larger firm size and have enough cash flow and retained earnings, they decided to finance their ventures by other means. Many women declared that they applied for bank loans only if they had no other choice. In fact, we found that women entrepreneurs are often reluctant to apply for bank financing. We will link this information later with women's desire to remain independent.

However, contrary to findings in the literature, our results showed that the women entrepreneurs in our sample frequently used bank loans to finance their start-up, especially those who had between one and ten employees. We can perhaps link these data with the Belgian context. In Belgium, employee costs are very high and, for women entrepreneurs, who create small structures with few funds, one of the problems can be having the money to pay personnel. We can link this information with the data where women told us that they borrowed money from banks only when they most needed it and that they preferred to avoid this prospect if they could. We need to validate this hypothesis with further research, but, if this is the case, it could have a bearing on an action plan, showing as it does the importance of helping small firm entrepreneurs (women but also men) to find funds to pay employees.

Barriers in access to financing and a firm's characteristics and strategic choices. Table 3 confirms the results that specific aspects by sector appear concerning barriers in access to financing. These barriers are more significant in the service and retail industries than in the other sectors. Indeed, $51 \%$ of the women entrepreneurs in these sectors identified these barriers as a key problem at the start-up stage, whereas the proportion falls to $31 \%$ of women in the industrial sector and $35.2 \%$ for the professionals. These women in the service and retail sectors also seem more likely than others to face problems relating to the lack of support from institutional organizations, when launching their businesses: $36.4 \%$ of them identified this barrier, compared to $21 \%$ of women in the industrial sector and $26 \%$ for the professionals.

The qualitative interview analysis provides added information about the reasons why women entrepreneurs in male-dominated sectors do not encounter problems in accessing financing. We find here no specific aspects relating to women, but we do find a gender effect! On the one hand, women entrepreneurs running ventures in male-dominated sectors had the feeling that bankers' confidence in them was due to the fact that they had male associates. On the other hand, women who had taken over a family business in those male-dominated sectors attributed the confidence that financiers placed in them to their firm's past (credit history), the business having been run historically by a man, and to their firm's reputation. Therefore, we may perhaps make the hypothesis that women entrepreneurs in male-dominated sectors may profit from some credibility in the eyes of financiers, which may in fact be related to a 


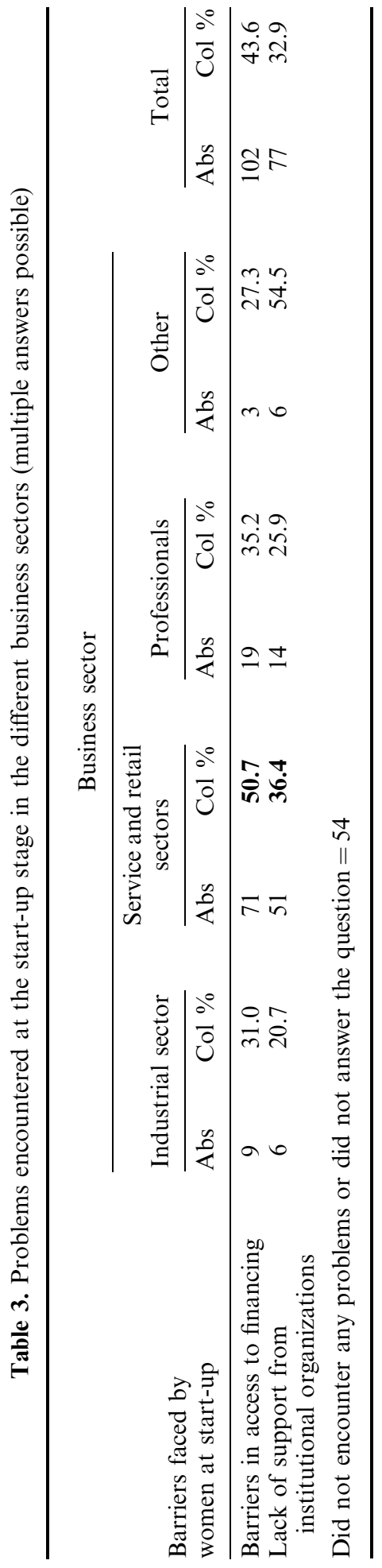


male history. This would confirm the existence of a gender effect. However, our data do not enable us to go further than just making a hypothesis. It would be interesting to explore this idea and to validate it in future research.

It must be underlined that the qualitative analysis of the interviews highlighted another gender effect. Indeed, contrary to the hypothesis of business characteristics, women entrepreneurs in the industrial sector were shown to encounter problems relating to gender, not with regard to business financing, but in terms of relationships with other stakeholders (mainly customers and suppliers) and with employees. However, these problems seemed to disappear once they had proved themselves as being able to manage the business, when women could even profit from a 'prestige' effect influencing financiers and other stakeholders.

\section{Individual Factors}

We also find an influence of human capital (experience, education, functional experience, etc.), social capital (social and business relationships) and personal cognition and goals (push and pull motivations, cognitive styles) upon financing patterns of women entrepreneurs.

Women perceived their lack of specific competence and knowledge as a problem encountered at the start-up stage in $22 \%$ of our sample. Women with lower levels of education are more likely to encounter problems in their access to financing than women with higher degrees of education. Indeed, nearly half the women with a diploma from secondary school faced this type of problem, far more than women with a high school or university diploma. It can also be seen that women who had followed additional training in management or in their business sector were less likely to face financing problems at start-up, in comparison with women who had not. It must be noted that these factors are related to the business sectors in which women entrepreneurs work. Indeed, women with higher education and additional training are running businesses mostly in traditionally male business sectors, which seem also to be the most advantageous in terms of financing.

However, we must draw attention to the fact that this result, if it can indeed be confirmed in the case of business creation, does not prevail in the case of a family business takeover. Women who took over the family business were shown to have mostly low levels of education and little additional training but, despite this, they had no problems with access to financing. In some cases, their business experience could partly explain this (in the case of women who had worked as an employee in the family business) but not for all of them. Indeed, some women took over the family business after their father or husband had died, or after an accident - without being prepared. In those cases, the qualitative analysis is complementary to the quantitative one, offering us a possible explanation. As we have seen before, these women's successful access to financing may be due to a reputation effect and/or related to the history of the man who was running the business before. Regarding their relationships with other stakeholders, however, these women needed some time to acquire credibility.

We can also see that the women had, for the most part, a lack of personal funds. This characteristic is linked both to their less qualified jobs and/or lower 
earnings (Orhan, 2001) and to their economic dependence as regards their husband's status.

Our quantitative data also show that $40 \%$ of the women entrepreneurs in our sample were not members of any network or professional association and declared a lack of information about external financing opportunities. The lack of support from networks $(34 \%)$, from institutional organizations $(33 \%)$ and sometimes from friends and family $(20 \%)$ was identified as a problem encountered at the start-up stage. A qualitative analysis of our interviews revealed that women entrepreneurs associated their lack of information with their preferences and behaviours in terms of financing sources (equity versus debt financing), and with their fear (fear of being turned down when applying for a loan; risk-aversion; fear of not being credible enough).

We were lucky to have enough money and that our firm did not necessitate important equipment investments. That's why we started with our personal savings. [...] But it was perhaps more due to the fact that we didn't know that there were other possibilities. For me, that is the most difficult aspect: the different financing methods. We did not want to lose our independence. I was afraid...but this fear was based on nothing: it was due to my lack of information. (M2)

Our research gives us information on women entrepreneurs' representations towards investors and the way women think of these potential funders, which may have a substantial influence on their behaviours. This information is not quantitative, but emerges from the interview analysis, and provides added value with regard to the quantitative data. We stated that the qualitative analysis revealed that women entrepreneurs seemed to apply for bank loans only if they had no other choice, and that they generally preferred to rely on their own assets. First, this attitude could come from the fear of being turned down when applying for a bank loan, as mentioned by several women. The reasons for this fear were diverse and often rational, either linked with the business sector or with the reality they experience as women: their family or professional status, their limited personal assets or the fear of not being credible enough as a woman. Women know about the importance of the firm's credit and the owner's personal history in a banker's decision. Their fear that their demands for bank loans will not be accepted is often a realistic one, if we look at the sector, the size of the firm, the perspective of growth and the women's characteristics.

When you are widowed and a self-employed woman, banks don't grant you loans so easily [...] because a self-employed worker is not $100 \%$ reliable, especially in our profession [nursing]. Being a widow is also a limit: if my husband was there ... He had a salary and thus the bank would have known that there was some regular income. But here being alone and a self-employed worker, I think that it would be a problem. (M6)

It is a matter of credibility ... a woman has to expend more energy than a man to convince the banker, to be credible. (M3) 
Second, our qualitative analysis revealed that the reluctance of women entrepreneurs to apply for bank loans could be due to their strong risk-aversion and their lack of trust towards bankers. Women perceived their risk-aversion as a problem encountered at the start-up stage in $34 \%$ of our sample.

One woman entrepreneur who used bank financing during the start-up process explained:

We use bank services just when it is necessary [...] but otherwise not. Banks have no possession here. We have a very important cash flow, and thus an enormous auto-financing capacity; business is good. (M9)

In answer to the question 'Have you ever had recourse to a bank loan?', one woman consultant, who did not use bank financing, declared:

Never. I have always been lucky in having good results. We had the required capital at that time and thus we thought that we didn't need a bank loan to start up our business, considering that we had enough money and we were confident enough about the future... So we preferred to invest what we already had. (M16)

Our qualitative analysis revealed that several women entrepreneurs linked their behaviour to the notion of dependence. Indeed, women had the feeling that requiring credit could reduce their independence, which was often one of their motivations for starting a venture in the first place. We also encountered the idea of managing the business budget in the same way as the household budget:

I still calculate and budget as a housewife! That is because of my upbringing ... Perhaps it is not your case [you are young], but it is mine: if you have $€ 100$ at your disposal, there is no way you can spend 110 ! I'm always seeking budget equilibrium, and I think that this is typical of women. (M2)

Female entrepreneurs frequently mentioned their financial prudence and riskaversion as women, arguing that they were saving their family from unconsidered debts.

If you talk with a young man or with a mature man, you will already have two different types of reasoning. I think that women have more frequently and more quickly this type of 'mature' reasoning, perhaps because we are more afraid of making a blunder [...] we feel responsible for our family. I would not say that men don't have this feeling at all, but I think women also fear the negative consequences at that level. (M5)

I had the chance to have the money available, so I didn't need a bank loan ... and that was one of our principles, and that is a principle we still have. This is due to the fact that we are still paying for the house, we have a child who is going to study in the future, and thus there are quite big expenses that we have to take into account. (M4) 
Third, it seems that women entrepreneurs base their decisions in terms of business financing more on the 'necessity' of investing, rather than the 'prestige' that could come from it.

Some women interviewed had the feeling that female entrepreneurs tended to pump less money than men into start-up because of their personality and preferences, also influenced by some of their cultural values.

I have the feeling that women try to start a business with less money than men. I am just thinking of a male colleague ... While I would think twice before buying a computer, he would have bought it already! There are many women in the business, and that is not the same ... but I don't know whether my observation is linked to the entrepreneur's sex or not. (M17)

Our qualitative analysis reveals that the personal preferences of women entrepreneurs may play a role in growth, showing that a lot of women want to be profitable, to survive, but not necessarily to accumulate capital. Our qualitative interview analysis also highlights a possible explanation, which is interesting with regard to gender: women often prefer not to grow, in order to maintain a good quality of life and to balance their work and family responsibilities. Women perceived work-life balance problems as ones encountered at the start-up stage in $54 \%$ of our sample. Another problem linked with time management is the fact that $55 \%$ of women in our sample perceived the excess of administrative tasks to be a real problem in the start-up and development stages.

\section{Discussion}

This research carries on from other studies undertaken on the financing of womenowned firms, showing that factors other than gender, mainly related to firm and owner characteristics and preferences, have an impact on the financing patterns and barriers in access to funding faced by female-owned ventures. However, in this present paper we argue that there still remains a gender effect, playing a role at different levels.

The gender notion includes both the concept of 'separation' and the concept of 'hierarchy'. The 'separation' is reflected by the differences between men and women entrepreneurs in terms of choices, preferences and needs for their business financing. The 'hierarchy' is reflected by the valorization ascribed to firm's attributes and entrepreneur's characteristics, in relation to financing.

In seeking to understand why women choose particular sectors for their ventures and have particular financing behaviour, we find answers in social structures, in the family roles of men and women and in the human and social capital of women. It is consistent with previous findings that highlighted the role of human and social capital in the way women entrepreneurs conceive their businesses and approach venture creation and performance (Brush, 1992), and for venture capital securing (Sargent and Young, 1991; Stuart et al., 1999).

Our results show that women entrepreneurs are not a homogeneous group, that there are differences between them both in terms of financing patterns of their ventures and in terms of firm's attributes and/or own characteristics. In our study, 
we identified three categories of women entrepreneurs, mainly in relation to the theories of human and social capital:

- women entrepreneurs with low levels of human, social and financial capital;

- women who took over the family business;

- women entrepreneurs with high levels of human, social and financial capital.

First, our results show, in line with previous research, that most women entrepreneurs have particular characteristics (limited social capital, low levels of education and experience, few personal savings, low wage, poor credit history) that lead them to choose particular business attributes (traditional business sectors, small size, limited growth). They seem to choose these sectors because they perceive them to be an extension of their family competencies and assume that, in order to succeed in these sectors, they do not need to have specific qualifications or experience. They also choose such sectors because they know that it is not necessary to invest much money either in the business start-up or in its development. Often they do not have a lot of personal savings and have a poor credit history. These results confirm previous findings (Ehlers and Main, 1998; Cooper Maysami and Goby, 1999) and may be related to the results of Anna et al. (2000), who showed that women's choice to pursue careers in traditional versus in non-traditional industries is influenced by their individual context, expectations and venture efficiency, offering an explanation to the concentration of women entrepreneurs in the retail and services industries. Also, these types of business sectors do not require large amounts of capital investment and thus contribute to the specific financing patterns of women-owned ventures. We find a further example of gender-typing in occupational distribution, with investors viewing these traditional sectors as lacking prestige. As Lindsey (2005, p. 286) states, 'women are situated in peripheral economic niches', which do not interest investors. Therefore, those women entrepreneurs encounter more financing barriers than others, due to the lack of valorization of their sectors, in terms of financing. As stated by Loscocco et al. (1991), the characteristics of women-owned businesses (mainly industry and size) reduce their financial success, in terms of sales volumes and revenue. In order to understand individual characteristics and behaviour (limited social capital, risk-aversion) of these women entrepreneurs, we need to use gender analysis and to consider women's position in the society. Birley (1989) emphasized the effect of women's position in society and of social roles on the types of businesses created, and on the financial and technical barriers encountered by women entrepreneurs. We have seen that the women entrepreneurs in our study did not like to spend money that they did not have at their disposal. Women's responsibility for the family and children were shown to increase their risk-aversion and to lead them to manage their firm's budget in the same way as the family budget, thus decreasing their financial investments and their reliance on bank financing. Moreover, it was shown that the way those women entrepreneurs perceive their firm's evolution and growth perspectives depends on their family responsibilities. It is consistent with the results of Brush (1997), who identified child and dependant care as an obstacle to the growth of women-owned businesses. In fact, it seems partly related to the personal objectives of women in traditional sectors, who tend to value life balance and security, rather than money and wealth (Anna et al., 2000; 
Clain, 2000). Indeed, entrepreneurship is seen by most women as a means to survive and to provide for family's needs, rather than a means for capital raise, and thus growth objectives are often given up to the benefit of a good life quality and of the reconciliation between their work and their family responsibilities. It should also be noted that these women are the least educated and trained, have the slightest credibility among financiers and the lowest growth and expansion capital, three of the main obstacles to growth identified by Brush (1997). Finally, these women entrepreneurs' preference not to rely on bank financing derives from their desire to remain entirely (economically) independent. It is interesting to examine this, in light of the profile of women entrepreneurs, who were often economically dependent before launching their business, either on their husband's income (housewives) or on government's help (women out of work, benefiting from social help). Sullivan et al. (1997) showed that women, who became self-employed to move out of poverty, define business success in terms of economic self-sufficiency or independence, and of personal rewards and satisfaction.

The second category of women entrepreneurs that our study revealed is composed of women with low educational levels, who took over the family business. These women are either owners of large, established firms or of non-traditional, highgrowth sectors ventures, and seem to have rather similar financing patterns to men (larger amounts invested, more use of bank financing). Furthermore, these women seem to not have encountered any problem in accessing funding, including bank financing. We have seen that, if those women did not encounter specific problems, it was often because they invested in the industry sector, which is traditionally maledominated. Moreover, they took over an already existing, capital-intensive firm, and thus benefited from its established notoriety. Women in male-dominated sectors were shown to have gained investors' trust based on the fact that they were working in association with a man or that they were running a firm previously owned by a man. Indeed, we showed that the credibility of a woman's company remained strongly related to a male history (the father, the husband, the partner) and that she felt that she would have to demonstrate that she could make it as well, if not better, than a man. Therefore, those women developed 'male' leadership styles, which correspond better to the 'entrepreneur' stereotype, better valued in terms of financing. More particularly, Anna et al. (2000) showed that women in nontraditional sectors seem to have higher expectations for profit than others. However, we could wonder whether their attitudes and behaviour are really linked to their own expectations, when considering the findings of Olson and Currie (1992), who show that women entrepreneurs in the construction sector tended to allow external factors to dictate their strategies, even if opposed to their personal values. Anyway, we can see that human capital (education, knowledge, experience) remains an decisive factor for investors' attitudes and decisions, at, at least, two levels: we have first shown the importance of the human capital of the man running the firm previously, and secondly the importance for the woman entrepreneur to demonstrate in practice the same, if not better, human capital as its predecessor. On the other hand, these women seem to have encountered some gender-related barriers in their dealings with other stakeholders (customers, suppliers, partners, etc.).

The last category of women entrepreneurs are women with a high education level, good social networks and personal funds, having created ventures in high-skilled 
jobs (women professionals, engineers). We could link this third category to the 'Swedish well-educated female entrepreneurs' studied by Holmquist and Sundin (1990), who stated that these women 'differed from other female entrepreneurs'. Our study's results showed that they tend to use external funding, and do not seem to encounter a lot of barriers in access to it, including bank financing. This could be explained by the good social networks these women have, which can be of great importance in terms of venture capital financing (Sargent and Young, 1991; Stuart et al., 1999). It can also be related to the strong self-confidence demonstrated by these women. They do not seem to question potential sexual biases in the financing process, and most of them see the grant of external funding as depending on the 'file' quality rather than the owner's sex. They also do not seek specific actions intended for women. This idea goes in the same direction as other research that approached financing barriers faced by women entrepreneurs as resulting from negative selfperceptions or bankers' perceptions by women, rather than resulting from external factors (Buttner and Rosen, 1992; Shragg et al., 1992). Contrary to the first category of women entrepreneurs, these women, who had mostly success stories, are risktaking. It shows that risk-aversion is not 'natural' and could potentially be worked on and deconstructed. It would be interesting in further research to see whether the provision of information to women entrepreneurs of the first group would contribute to a decrease in their fear and a modifying of their financing behaviour. If so, this would enable us to question the biological theories of gender, which explain women's behaviour in terms of a 'natural' risk-aversion. Indeed, if providing information to women entrepreneurs and working with them on their behaviour (e.g. seminars on self-confidence) were seen to imply a variation in women's behaviour towards financing and a decrease in their fear, this would be an argument in favour of a sociological explanation for risk-aversion and financing behaviour, rather than a biological one. Finally, we must emphasize that, for this third category of women entrepreneurs, our results as well as previous literature (Green and Cohen, 1995; Buttner and Moore, 1997; Fasci and Valdez, 1998), show that the decision to become self-employed and to create a business was motivated by two gender aspects. First, most of them launched their own venture, because as salaried workers, they had come across the famous 'glass ceiling'. This means that the hierarchical models of the salaried world did not enable them to put into practice the competences acquired. Second, a lot became self-employed as they wanted to better balance their family and work responsibilities. The idea was not to work less (accordingly with their desire to use their competences), but to be more flexible and independent in terms of work time schedules.

Out of all of this comes the interest to develop action points in order to work on and improve the financing of women-owned ventures. We propose to read these action points with a 'separation/hierarchy' reading grid.

A lot of initiatives are constructed around research results showing that women entrepreneurs choose sectors where they need only small initial amounts and which allows them to avoid dependency on bankers. Current initiatives for women propose solutions such as micro-loans (e.g. in Belgium, we can mention the project 'Femmes d'affaires - Affaires de femmes'). These initiatives, which were initially used in the developing countries, are now applied in the so-called developed countries, where they could respond to some of the specific needs of women 
entrepreneurs with low revenue profiles. However, in the light of past experiences (Servon, 1996; Cook et al., 2001; Dumas, 2001), it seems that in order to achieve the expected results, various support services (mentoring or networking programmes, social training, women's empowerment) must be implemented along with the financial support. One must also pay attention to the fact that such initiatives could create a ghetto, particularly if this type of solution is only proposed for women and not for men in similar situations. In addition, these types of microloans programmes could form a vicious circle, by reinforcing women's financing behaviour which does not favour growth and long-term viability. Ehlers and Main (1998) highlighted these biases, explaining that these types of programmes could in fact reinforce the existing business segregation and encourage women to maintain their economic vulnerability.

In our study, women owners of large, established firms, or with ventures in nontraditional, high-growth sectors, did not seem to encounter problems in accessing funding, including bank financing. This emphasizes the need for action towards horizontal desegregation of sector choice, with the view of encouraging women to create ventures in high-value sectors, which are of interest to investors. It also implies a consideration of choices made in terms of education channels and the need to work on stereotypes. However, this often implies for women to have a high diploma level (e.g. initiatives aiming at accompanying women in exact sciences channels). Nevertheless, we must also note that there are high-growth and valuable sectors in terms of financing, which do not necessitate such long and high education (e.g. logistics).

It would also be useful to identify, with the help of bankers and investors, which channels in women's business sectors would be valuable for potential investors and which ones could invest in, in order to differentiate them and be able to offer added value. Further research could be undertaken to enhance the understanding of traditionally female-dominated sectors, which seem to be of little interest to financiers, in order to identify the channels that would attract investors. It could also contribute to increase the visibility of the economic profitability of traditionally female-dominated sectors, to show their economic weight and innovative potential, with the aim of gaining the financiers' interest. The problem of women entrepreneurs' visibility was raised by Baker et al. (1997).

Finally, our results showed, in line with the existing literature, that personal cognitions and goals of some categories of women entrepreneurs regarding entrepreneurship, bank financing and growth perspectives, had negative effects on their access to external funding. It would be useful to develop training programmes for women working on their abilities and competences, in order to enhance their know-how (knowledge in terms of accounting, business plan, human resources management), and their behavioural skills (assertiveness, risk-aversion, negotiating aptitude).

\section{Conclusion}

The main objective of our study was to identify women entrepreneurs' specificities in terms of financing and to examine the relationship between financing patterns and barriers and gender from the woman entrepreneur's viewpoint. 


\section{C. Constantinidis et al.}

According to our results, it seems that there are indeed some specific financing patterns and barriers for a number of women entrepreneurs. However, we have also highlighted that women entrepreneurs are not a homogeneous group, and that we could differentiate them according to human, social and financial capital variables.

Consequently, the primary point for further research and action is to be able to cross over the different dimensions, in particular to work on the differences between men and women entrepreneurs, but also to approach women entrepreneurs in their diversity. It thus implies to cross over the variable 'sex' and the human, social and financial variables.

Our findings show that there are gender effects, either related to 'separation' (differences in terms of choices, preferences and needs for business financing) or to 'hierarchy' (valorization in terms of the firm's attributes and the entrepreneur's characteristics, as regards financing) phenomena. It calls for future research and action that pay special attention to these two kinds of gender biases, as well as to the family and social roles of men and women, and to the women's position in the society.

\section{Acknowledgements}

This research was funded by a grant from the European Social Fund Agency, Equal Programme 2003-2005 (Diane project).

\section{Notes}

1 Gatewood et al. (2003) proposed an annotated bibliography around this subject.

2 The complete set of data is available in the Diane report 'Women entrepreneurs and training, financing and networks. National report (Belgium)' (Cornet et al., 2004), on the website: www.amazone.be (Diane Project).

3 The term 'women as single owners' refers to sole proprietorships with a single owner. The term 'women in association' refers to partnerships (unincorporated businesses) with two or more owners or to women administrators of corporations (incorporated businesses).

4 National Social Security Institute for the Self-Employed (www.inasti.be).

5 Louise St-Cyr, Director of the 'Chaire de développement et de relève de la PME', HEC (email: louise. st-cyr@hec.ca).

6 Union des Classes Moyennes, Mons-Hainaut (entrepreneurship centre).

7 In terms of United States dollars (US\$), €1 corresponds to approximately US\$1. The conversion rate at 16 September 2002 (the time of the questionnaire survey) was the following: $€ 1=$ US $\$ 0.97$.

\section{References}

Angus Reid Group (2000) Financing services to Canadian small and medium size enterprises, Report on focus group research, July.

Anna, A. L., Chandler, G. N., Jansen, E. and Mero, N. P. (2000) Women business owners in traditional and non-traditional industries, Journal of Business Venturing, 15(3), pp. 279-303.

Baker, T., Aldrich, H. E. and Liou, N. (1997) Invisible entrepreneurs: the neglect of women business owners by mass media and scholarly journals in the U.S.A., Entrepreneurship and Regional Development, 9, pp. $221-238$.

Birley, S. (1989) Female entrepreneurs: are they really any different?, Journal of Small Business Management, 27(1), pp. $32-37$. 
Boden, R. J. and Nucci, A. R. (2000) On the survival prospects of men's and women's new business ventures, Journal of Business Venturing, 15(4), pp. 347-362.

Brush, C. G. (1992) Research on women business owners: past trends, a new perspective and future directions, Entrepreneurship Theory and Practice, 16(4), pp. 5-30.

Brush, C. G. (1997) Women-owned businesses: obstacles and opportunities, Journal of Developmental Entrepreneurship, 2(1), pp. 1-24.

Buttner, E. H. and Moore, D. P. (1997) Women's organizational exodus to entrepreneurship: self-reported motivations and correlates with success, Journal of Small Business Management, 35(1), pp. $34-46$.

Buttner, E. H. and Rosen, B. (1992) Rejection in the loan application process: male and female entrepreneurs' perceptions and subsequent intentions, Journal of Small Business Management, 30(1), pp. 58 - 65.

Carter, N. M., Brush, C. G., Greene, P. G., Gatewood, E. and Hart, M. M. (2003) Women entrepreneurs who break through to equity financing: the influence of human, social and financial capital, Venture Capital, 5(1), pp. 1-28.

Carter, S. and Rosa, P. (1998) The financing of male and female owned-business, Entrepreneurship and Regional Development, 10(3), pp. 225-241.

Center for Women's Business Research (2000) Women-owned firms attract investors for business growth. Available at: http://www.nfwbo.org/pressreleases/7-18-2000/7-18-2000.htm (accessed 14 May 2005).

Center for Women's Business Research (2005) Top facts about women-owned businesses. Available at: http://www.nfwbo.org/topfacts.html (accessed 14 May 2005).

Chaganti, R., DeCarolis, D. and Deeds, D. (1995) Predictors of capital structure in small ventures, Entrepreneurship Theory and Practice, 20(2), pp. 7-18.

Clain, S. H. (2000) Gender differences in full-time self-employment, Journal of Economics and Business, 52(6), pp. $499-513$.

Cliff, J. E. (1998) Does one size fit all? Explaining the relationship between attitudes towards growth, gender and business size, Journal of Business Venturing, 13(6), pp. $523-543$.

Coleman, S. (2000) Access to capital and terms of credit: a comparison of men- and women-owned small businesses, Journal of Small Business Management, 16(5), pp. 232-243.

Coleman, S. (2004) Access to debt capital for women- and minority-owned small firms: does educational attainment have an impact?, Journal of Developmental Entrepreneurship, 9(2), pp. 127-143.

Connell, R. W. (2002) Gender (Cambridge: Polity Press and Blackwell Publishers).

Cook, R. G., Belliveau, P. and VonSeggern, K. L. (2001) A case study of microenterprise training: beta test findings and suggestions for improvement, Journal of Developmental Entrepreneurship, 6(3), pp. $255-267$.

Cooper Maysami, R. and Goby, V. P. (1999) Female business owners in Singapore and elsewhere: a review of studies, Journal of Small Business Management, 37(2), pp. 96-105.

Cornet, A., Constantinidis, C. and Asandei, S. (2004) Etude comparative des résultats internationaux (Espagne/Belgique), Working Paper, projet Diane, dans le cadre du réseau Nereidas, juin 2004, recherche FSE, commanditée par Markant (CEZOV).

Danmanville, P. and Hurel, F. (2001) Les femmes et la création d'entreprise (Agence Pour la Création d'Entreprises, Collection Focus).

Dumas, C. (2001) Evaluating the outcomes of micro-enterprise training for low income women: a case study, Journal of Developmental Entrepreneurship, 6(2), pp. 97-128.

Ehlers, T. B. and Main, K. (1998) Women and false promise of micro-enterprise, Gender and Society, 12(4), pp. 424-440.

Fabowale, L., Orser, B. and Riding, A. (1995) Gender, structural factors, and credit terms between Canadian small businesses and financial institutions, Entrepreneurship Theory and Practice, 19(4), pp. $41-66$.

Fasci, M. A. and Valdez, J. (1998) A performance contrast of male- and female-owned small accounting practices, Journal of Small Business Management, 36(3), pp. 1-17.

Gatewood, J. E., Carter, N. M., Brush, C. G., Greene, G. P. and Hart, M. M. (2003) Women Entrepreneurs, their Ventures, and the Venture Capital Industry, an Annotated Bibliography, Report 2003:1 (Stockholm: ESBRI).

Green, E. and Cohen, L. (1995) Women's businesses: are women entrepreneurs breaking new ground or simply balancing the demands of women's work in a new way?, Journal of Gender Studies, 4(3), pp. $297-314$ 


\section{C. Constantinidis et al.}

Greene, P. G., Brush, C. G., Hart, M. M. and Saparito, P. (2001) Patterns of venture capital funding: is gender a factor?, Venture Capital, 3(1), pp. 63-83.

Haines, G. H., Orser, B. J. and Riding, A. L. (1999) Myths and realities: an empirical study of banks and the gender of small business clients, Revue Canadienne des Sciences de l'Administration, 16(4), pp. $291-307$.

Heidrick, T. and Johnson, S. (2002) Financing SMEs in Canada: barriers faced by women, youth, Aboriginal and minority entrepreneurs in accessing capital. Phase 2: gap analysis and recommendations for further research. Research Paper prepared for the Small Business Policy Branch as part of the Small and Medium-sized Enterprise (SME) Financing Data Initiative, Industry Canada, March 2002.

Heidrick, T. and Nicol, T. (2002) Financing SMEs in Canada: barriers faced by women, youth, Aboriginal and minority entrepreneurs in accessing capital. Phase 1: literature review. Research Paper prepared for the Small Business Policy Branch as part of the Small and Medium-sized Enterprise (SME) Financing Data Initiative, Industry Canada, January 2002.

Holmquist, C. and Sundin, E. (1990) What's special about high-educated women entrepreneurs, Entrepreneurship and Regional Development, 2, pp. 181-193.

Kangasharzu, A. (2000) Growth of the smallest: determinants of small firm growth during strong macroeconomic fluctuations, International Small Business Journal, 19(1), pp. 28-43.

Kergoat, D. (2000) Division sexuelle du travail et rapports de sexe, in: H. Hirata, F. Laborie, H. Le Doaré and D. Senotier (eds) Dictionnaire critique du féminisme, pp. 35-44 (Paris: PUF).

Légaré, M.-H. (2000) La performance de l'entreprise en fonction du sexe du propriétaire: l'entrepreneuriat féminin et le cas des PME manufacturières québécoises. Mémoire présenté en vue de l'obtention du grade de maître ès sciences, Montréal, Ecole des Hautes Etudes Commerciales Affiliée à l'Université de Montréal.

Lindsey, L. L. (2005) Gender Roles: A Sociological Perspective (Upper Saddle River, NJ: Prentice-Hall).

Loscocco, K. A., Robinson, J., Hall, R. H. and Allen, J. K. (1991) Gender and small business success: an enquiry into women's relative disadvantage, Social Forces, 70(1), pp. 65-85.

McKechnie, S. A., Ennew, C. T. and Read, L. H. (1998) The nature of the banking relationship: a comparison of the experiences of male and female small business owners, International Small Business Journal, 16(3), pp. 39-55.

OECD (Organization for Economic Cooperation and Development) (2000) Background Report/ Workshop No. 3: Financing for women-owned business. From OECD Conference: Women Entrepreneurs in SMEs: Realising the benefits of globalisation and the knowledge-based economy, Paris, 29-30 November.

Olson, S. F. and Currie, H. M. (1992) Female entrepreneurs: personal value systems and business strategies in a male-dominated industry, Journal of Small Business Management, 30(1), pp. 49 - 57.

Orhan, M. (2001) Women business owners in France: the issue of financing discrimination, Journal of Small Business Management, 39(1), pp. 95-102.

Ratté, S. (1999) Les femmes entrepreneures au Québec: Qu'en est-il? (Montréal: Fédération canadienne de l'entreprise indépendante).

Riding, A. L. and Swift, C. S. (1990) Women business owners and terms of credit: some empirical findings of the Canadian experience, Journal of Business Venturing, 5(5), pp. 327-340.

Robb, A. and Wolken, J. (2002) Firm, owner and financing characteristics: differences between femaleand male-owned small businesses, Finance and Economics Discussion Series, Division of Research and Statistics and Monetary Affairs, Federal Reserve Board, Washington, DC No. 2002-18.

Sargent, M. and Young, J. E. (1991) The entrepreneurial search for capital: a behavioural science perspective, Entrepreneurship and Regional Development, 3, pp. 237-252.

Servon, L. J. (1996) Microenterprise programmes and women: entrepreneurship as individual empowerment, Journal of Developmental Entrepreneurship, 1(1), pp. $31-55$.

Shragg, P., Yacuq, L. and Glass, A. (1992) Study of barriers facing Albertan women in business, Journal of Small Business and Entrepreneurship, 9(4), pp. 40-49.

St-Cyr, L. (2002) Les femmes entrepreneurs Québécoises: taille et gestion. Compte rendu d'une recherche, Montréal, Ecole des Hautes Etudes Commerciales Affiliée à l'Université de Montréal.

St-Cyr, L., Hountondji, S. and Beaudoin, N. (2003) Mémoire présenté au Groupe de travail du Premier Ministre sur les femmes entrepreneures, Chaire de développement et de relève de la PME, Ecole des Hautes Etudes Commerciales Affiliée à l'Université de Montréal. 
Stuart, T. E., Hoang, H. and Hybels, R. (1999) Interorganizational endorsements and the performance of entrepreneurial ventures, Administrative Science Quarterly, 44(2), pp. 315-349.

Sullivan, P., Halbrendt, C., Wang, Q. and Scannell, E. (1997) Exploring female entrepreneurship in rural Vermont and its implications for rural America, Economic Development Review, 15(3), pp. $37-42$. 